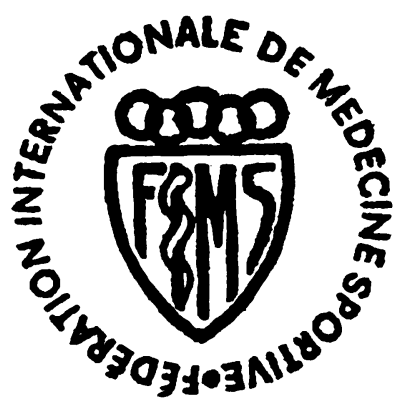

\title{
FIMS APPEAL ON WORLD HEALTH DAY DEDICATED TO
}

\author{
"SMOKING AND HEALTH"
}

WHO asked FIMS to support activities for the World Health Day 1980 (7th April) which is dedicated to the very actual problem "Smoking and Health".

The Scientific Commission of FIMS has worked out a proclamation which was accepted by the Executive Committee.

At the occasion of the last joint meeting at Moscow in October 1979, it was agreed that the proclamation is sent to the Editors of the Journals of Sports medicine throughout the world asking them to publish this paper together with a short statement against smoking.

In the name of the president of the FIMS I sent you the proclamation and ask you to support the WHO purpose by publishing it in the British Journal of Sports Medicine.

Prof. Dr. S. E. Strauzenberg

The fact that smoking contributes significantly to the increase of morbidity and mortality in some important diseases threatening public health was underlined by a World Health Assembly resolution already in $1970(6)$ and since then has been accentuated by WHO-Expert-Committees in 1974 and 1978 as well as by the results of numerous other studies.

It is well known that the most important noxious components in cigarettes are cancerogenic substances as well as nicotine, carbon monoxide and traces of metallic ingredients liberated by burning tobacco and inhaled in a harmful concentration.

The direct relation between a significant increase in the incidence of lung cancer and the duration and quantity of inhaling tobacco smoke has been verified for both sexes in many examinations (22). Moreover in smokers manifestations of changes in the bronchial epithelium $(4,14,10)$, hypersensitivity of the bronchial system to all kinds of respiratory noxes $(4,16)$ and discrete indications of incipient obstructive disturbances of ventilation $(10)$ can be verified very early and increase with the duration of smoking $(3,4,9,21,25)$.

Another direct connection between smoking has been proved for the rising incidence of central and peripheral vascular diseases. The morbidity in myocardial infarction especially in younger people as well as the mortality are significantly affected by smoking $(1,2,3,24)$. Thrombo angiitis obliterans of the arteries of the lower extremities in younger people is found almost exclusively in heavy smokers. There is also a greater risk for cerebrovascular disorders. Several partial factors such as accelerated formation of atheromas (1), increased coagulability $(23,24)$, increased cholesterol concentration in blood and a decrease in HDL concentration (7) as well as impaired oxygen dissociation (11) precipitate the manifestation of these vascular diseases in a combined way, mutually potentiating their influence.

There are indications that the widespread propagation of the growing knowledge about the perilous influence of smoking is not ineffectual to many people. The distinct decrease of the number of smokers among British physicians, which goes along with a similar decrease in the morbidity of bronchial carcinomas (5), points in this direction as does the reduced frequency of smoking among medical students in England, which declined from $52 \%$ to $28 \%$ in males and from $35 \%$ to $16 \%$ in females. On the other hand, however, it must be stated that, contrary to their better knowledge, about one quarter of all students continue to smoke (12). Further it cannot be overlooked that it is generally the manifest impairment of health rather than preventive aspects that influence smoking habits. Investigations of Herman and Lies (9) revealed that the portion of the population who gave up smoking because of prophylactic reasons already prior to the onset of health troubles only amounts to $28 \%$ of ex-smokers whereas $45 \%$ stopped smoking only after various symptoms became evident. 
Although a growing number of people abandons smoking after 10-20 years, the overall number of inhaling smokers continues to rise. In industrial countries, in particular in big cities, the number of female smokers increases faster than that of males $(22,27)$. A similar trend is found in young people of both sexes so that in the big cities of Central Europe up to $60 \%$ of the boys and up to $40 \%$ of the girls regularly smoke already at an age of $16(8,15,19,20,27)$.

In this context we must not forget that - together with smokers in closed rooms - non-smokers also are forced to inhale the polluted air and become "passive"-smokers. Therefore smokers may be put in a line together with other environment-polluting processes. In view of the fact that smoking is an avoidable risk to health, which, not only in the highly industrialized countries but increasingly also in developing countries causes disablement and contributes to premature death, the fight against tobacco abuse by exerting an instructive and educational influence has become one of the most important preventive tasks of the physician.

The International Federation of Sports Medicine (FIMS) therefore unites with all those who protest against the publicity for smoking. Instead of campaigning for non-smoking, mass media intentionally or carelessly continue to present as a standard idol smart young sportsmen who smoke continually. Within the framework of these tasks the sports physician takes a particular liability because three aspects of smoking concern his specific field of work directly:

1. The activity of the sports physician is not limited to the treatment of disease or injury. His consistent endeavour is to maintain health and performance so that his work is characterised by a pronounced preventive orientation.

2. A substantial portion of the population under the care of the sport physician is young, at a decisive age where they may become chronic smokers or may stay non-smokers. In this context it is noteworthy to know that people who start to smoke heavily at an early age will face greater difficulties if later in life they try to give up smoking (13).

3. Performance in sport is impaired by chronic tobacco consumption (17). Even though the decrease of physical capacity is not always significant when tested spiroergometrically (18) it becomes more pronounced at high work loads, with growing age, and increasing duration of smoking. Moreover impaired physical performance is an argument which, in young people, generally evokes a stronger motivation against smoking than the fear of disease that "might occur in a distant and uninteresting future". About $1 / 4$ of young people do not smoke because they believe in an impairment of their performance (2).

But there is still an additional reason why the sports physician has a good chance to contribute successfully in the fight against cigarette abuse: The greatest number of sports physicians do not smoke or smoke only occasionally. So his influence is not impaired by bad personal example which in many cases renders the role of the physician as a health educator somewhat questionable.

The International Federation of Sports Medicine (FIMS) directs this appeal to all sports physicians and National Societies of sports medicine to take an active part in the fight against tobacco abuse. Especially on the occasion of the World Health Day on April 7, 1980 - a day dedicated to the worldwide topic 'Smoking and Health' - they are asked to contribute to this highly topical health-endangering and avoidable risk.
A. Dirix
L. Prokop
Chairman of the Inter-federal
President of FIMS
S.E. Strauzenberg
Chairman of the
Medical Commission
Scientific Commission

\section{REFERENCES}

1. Avandilov, G. G., Kolenova, V. I., Ponomarenko, O. V., 1965. "Tobacco smoking and the degree of arterioscleritic lesions of the coronary ateries and aorta". Karkeologiya $5,30$.

2. Biener, K. 1968. “Kausalität und Motivation des Tabak-Konsums der Jugend. Münch.med.Wschr., 110, 20

3. Bosse, R., Age, 1975. “Smoking Inhalation and Pulmonary Function". Arch.Environ. Health 30, 495

4. Colley, J. R., Douglas, J. W., Reid, D. D., 1973. “Respiratory Diseases in Young Adults - Influence of Early Childhood, Lower Respiratory Tract Illness, Social Class, Air Pollution and Smoking". Brit.med.J. 3, 195.

5. Doll, R., Pike, M. C., 1972. J. Roy, Coll.Phys. 6, 216

6. Fletcher, C. M., Horn, D., 1970. WHO-Chronicle 24, 345. 
7. Garrison, R. J., Kannel, W. B., Feinleb, M., Castelli, W. P., Mc Namara, P. M., Padgett, S. J., 1978. “Cigarette smoking and HDL Cholesterol"'. Arteriosklerosis, 30, 17.

8. Hanley, J. A., Robinson, J. C., 1976. “Cigarette smoking and the Young: a National Survey”. CMA J., $114,511$.

9. Hermann, H. and Liehs, F., 1977. “Die Rauchgewohnheiten and Ihr Einfluss auf die Entwicklung chronisch broncho-pulmonaler Erkrankungen - Ergebnisse der epidemiologischen Bronchitisforschung in der DDR". Z.Erkrank.Atm.-Org. 158, 5.

10. Hüttemann, U., Oswald, P., Lode, H. und Huckauf, H., 1971. "Veränderungen der Lungenfunktion Jugendlicher als Folge langjährigen Zigarettenrauchens". D.Med.Wschr., 46, 1791

11. Kjeldsen, K., et, al., 1974. Circ.Res. 43, 229.

12. Lester, E., 1977. "Smoking behaviour in medical students". Brit.med.J. 2, 1630

13. Mc Kennel, A. C., Thomas, R. K., 1967. "Adults and Adolescents' Smoking Habits and Attitudes". London,

14. Niewoehnen, D. E., Kleinermann, J., Rice, D. B., 1974. "Pathologic Changes in the Peripheral Airways of Young Cigarette Smokers". New Eng.J.Med. 291, 755

15. Piper, G. W., Matthews, V. L., 1975. "The Saskatoon Smoking Study - Five Years Trends. A Report to the Department of National Health and Welfare". Canada, Ms.Druck, 89 s.,

16. Scharkoff, H., Herrmann, G., Niegsch, E., Schalk, W., Tetzner, W., 1977. “Die Epidemiologie der bronchialen Hyperreaktivität". Z.Erkrank.Atm.Org. 147, 122.

17. Schmidt, F., 1972. “Gesundheitsschäden des Rauchens im Kindes - und Jugendalter". Med.Welt 23, 921.

18. Schwalb, H. und Fackler, R., 1970. "Untersuchungen über die kardiopulmonale Leistungsfähigkeit bei Rauchern". Arch.Kreislaufforschg. 62, 167.

19. Seely, J. E., Bouhys, E., 1971. "Cigarette Smoking: Objective Evidence for Lung Damage in Teenagers". Science $172,741$.

20. Serice, M., Freour, P., Bernadou, M., Roger, J. C., 1973. “La Consommation de Cigarettes Dans un Groupe de Jeunes Scolaires de 12 a 14 Ans en 1972". Revue d'Epidemiologie Medecine Sociale et Santé Publ. 21, 723.

21. Tager, J. H., Speizer, F. E., 1976. “Risk estimates for chronic bronchitis in smokers. A study of male-female differences". Amer.Rev.Respirat.Dis. 113,619.

22. Terry, L., 1973. “Combatting the Health Hazards of Smoking”. Ca.Cancer J. Clinic. 23, 362.

23. United States Department of Health, Education and Welfare. 1973. "The health consequences of smoking". DHEW Publication No. 73, 8704, 167.

24. US Department of Health, Education and Welfare. 1974. "The health consequences of smoking". DHEW Publication No. 74, 8704, 93.

25. Woolf, C. R., Clinical Findings, 1974. "Sputum Examinations and Pulmonary Function Test related to the smoking habit of 500 Women". Chest 66, 652.

26. Wuthe, H., Petro, W., Müller, E., Pohl, S. und Vogel, J., 1977. “Rauchen im Kindesalter - Ergebnisse einer Schuluntersuchung in Berlin-Karow 1976". Z.Erkrank.At.Org. 148, 25.

27. Zuber, L., Zuber, R., 1973. “Rauchgewohnheiten bei Schülern der Klassen 5 - 12 der Erweiterten Oberschule, derPolytechnischen Öberschule, der Berufsschule und der Sonderschule der Kreisstadt Zeulenroda". Z.ärztl. Fortbildg. 67, 1267. 